\title{
Indo-Persian and Urdu Speaking Elites' Discourses on the Modern European Science
}

\author{
Gulfishan Khan*
}

(Received 30 March 2018; revised 17 May 2018)

\begin{abstract}
Muhgal court played a dynamic role in the pursuit of knowledge and investigation in medieval India. Science and Technology was also a major preoccupation for the Indo-Persian intelligentsia and there existed a public space for the scientific enquiry and research. India, over the centuries had borrowed extensively from, and contributed generously to the scientific and technical knowledge of neighbouring regions, from the Middle East and Central Asia to China and Southeast Asia. Therefore, in the eighteenth and nineteenth centuries the encounter between the modern European science and its counterpart was not one of simple conquest and diffusion from the West to the East. Rather an intellectual engagement with new ideas was inevitable which need to be appreciated in a proper historical perspective.
\end{abstract}

Key words: Abū Tālib ibn Muhammad Isfahānī, Tafaz̧ul Husain Khān, Karīm Khān, Siyāhatnāma, (Book of Travels), Sayyid Aḥmad Khān, Zīj-i-jadīd Muhammad Shāhī.

\section{SCienCe AND Technology:} The Medieval Legacy

India's scientific tradition was quite vibrant in the centuries prior to establishment of colonial rule. Scientific and technical influences from the Islamic East such as the spinning wheel, paper, the stirrup and the Persian wheel introduced by the Turks, were readily assimilated and absorbed. New mechanical devices and scientific instruments such as the magnetic compass, astrolabes, sun-dials, astronomical and water clocks entered India (Siddiqui, 1993; 2009). Mughal court was a vital source of patronage for science and technology as evident from the multifarious activities of Fathullāh Shirazī (15261589) (Alvi and Rahman, 1968; 2011). The exchange of ideas transpired in the fields as diverse as agriculture, architecture, astronomy, chemistry, medicine, metallurgy, textile production, shipbuilding and armaments (Qaisar, 1982; Habib,
1980, pp.1-34; Sen, 1970, pp. 32-46). Rational enquiry and research, circulation of scientific and technical knowledge signified in elite preoccupations such as the compilation of scientific works, commentaries, translations from Arabic into Persian, Sanskrit and vice versa was an integral part of traditional elite culture. Numerous scientific and technical treatises were composed which proliferated throughout India and the extraordinarily diverse literature is preserved in the libraries of South Asia, and Europe (Rahman, 1982).

In the first half of the eighteenth century financially strained Mughal court sponsored largescale scientific projects such as the establishment of astronomical observatories and compilation of astronomical data called Zīj-i-jadìd Muhammad Shāhī. Sayyid Aḥmad Khān (1817-1898) described it as a unique opportunity of crosscultural scientific exchange between the

\footnotetext{
* Associate Professor in Medieval Indian History, Centre of Advance Study, Department of History, Aligarh Muslim University, Aligarh, Email: gulfishankhan@gmail.com
} 
indigenous and European scientific tradition. But, for the Mughal elite, astronomy was a science in the service of the empire, envisioned less for utilitarian and cultural purposes, as the fixing of regnal year remained one of the major goals of the astronomers working under the royal patronage. Preparation of a new calendar and almanacs was an old fad rooted in the nature of predominantly agrarian Indian economy. A century earlier Maulānā Farīd al-Dīn ibn Hāfiz Ibrāhīm Dehlawī (d.1629), the royal astronomer of the Emperor Shāh Jahān, had also prepared astronomical-mathematical tables known as the Zūj-i-Shāhjahān̄̄ also called Kārnāmāhāi Sāhab Qìrān-i-Sāni (A Chronicle of the Second Lord of the auspicious planetary Conjunction) (Khan, 2009, pp.39-76; 2017; pp.502-07). The work, regarded a monumental achievement, was translated into Sanskrit as Siddhāntasindhu by Nityānandā, a court astronomer. Mīrzā Khair Allāh Khān Muhandis, Shaikh Muhammad 'Abid, Rājā Jai Singh (1688-1743), and their achievements continued to be commemorated by the successive generation of indulgent Indo-Persian and Urdu speaking elite. A Mughal scientist Mu'tamad Khān Rustam bin Diyānat Khān Qubād Harīsī Badakhshī (d.1705) also visited Europe/Portugal, where he learnt Latin and translated Jesuit astronomer and mathematician Christoph Clavius' (1537-1612) Eight Books of Gnomics into Arabic. Mu'tamad Khān was a scholar of Sanskrit and would have learnt Greek and Latin sciences (Khan, 1998, pp.40-41, p. 270). His voluminous translation entitled Kitāb al-Maqāȳis (Book of Measures) which has no preface remains to be studied (See Figs. 1 \& 2).

With the British conquest of Bengal European scientific ideas began to be diffused among a limited number of members of intelligentsia. Major European scientists such as Copernicus and Newton and their marvellous achievements became subject of discourse of the colonized elite. The Indo-Islamic educated elite exchanged their knowledge on diverse issues with the British scholars and scientists, mostly members of the Asiatic Society of Bengal, such as Sir John Shore, William Jones and Reuben Burrow (1747-

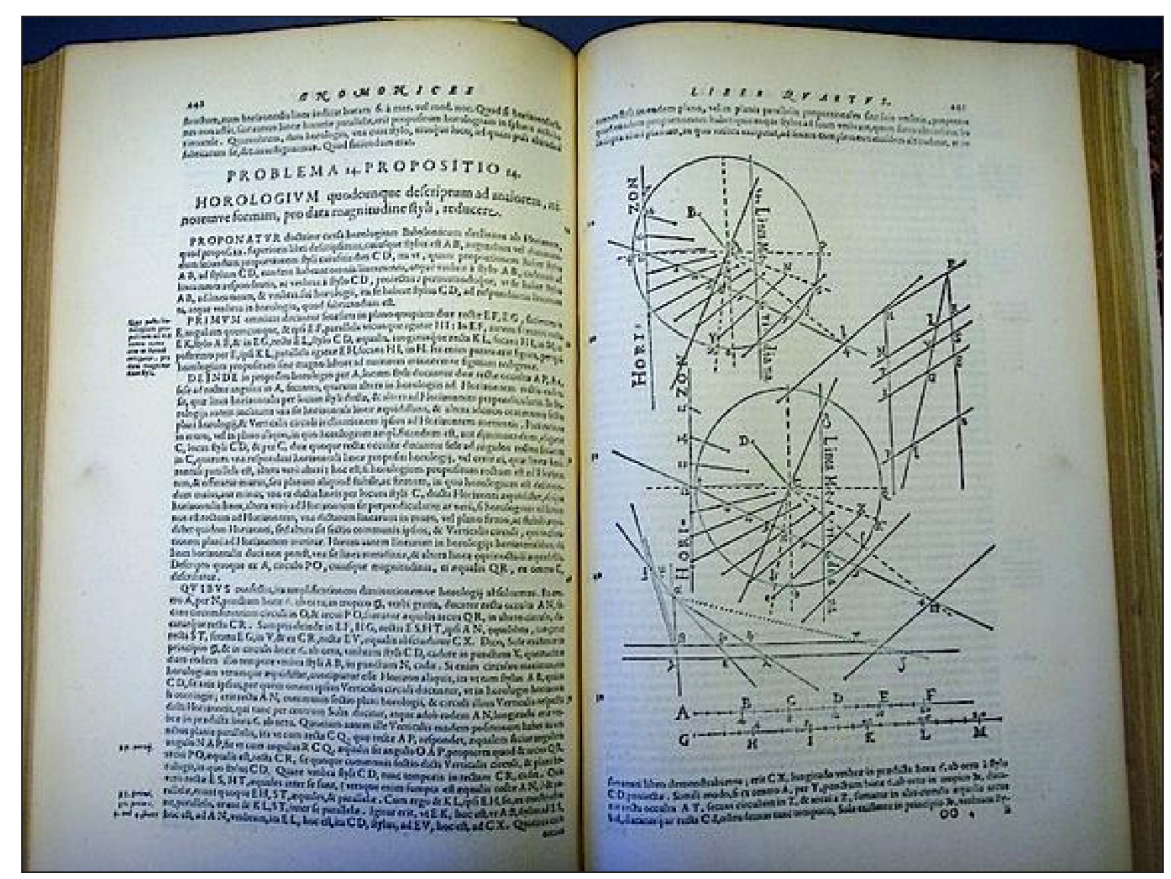

Fig. 1. Book 4 of Christoph Clavius, Gnomonices Libri Octo, On the art of Gnomonics Timekeeping through the use of a sundial), was published in 1581. (533.k.2, pp. 442-43). (Courtesy: British Library) 


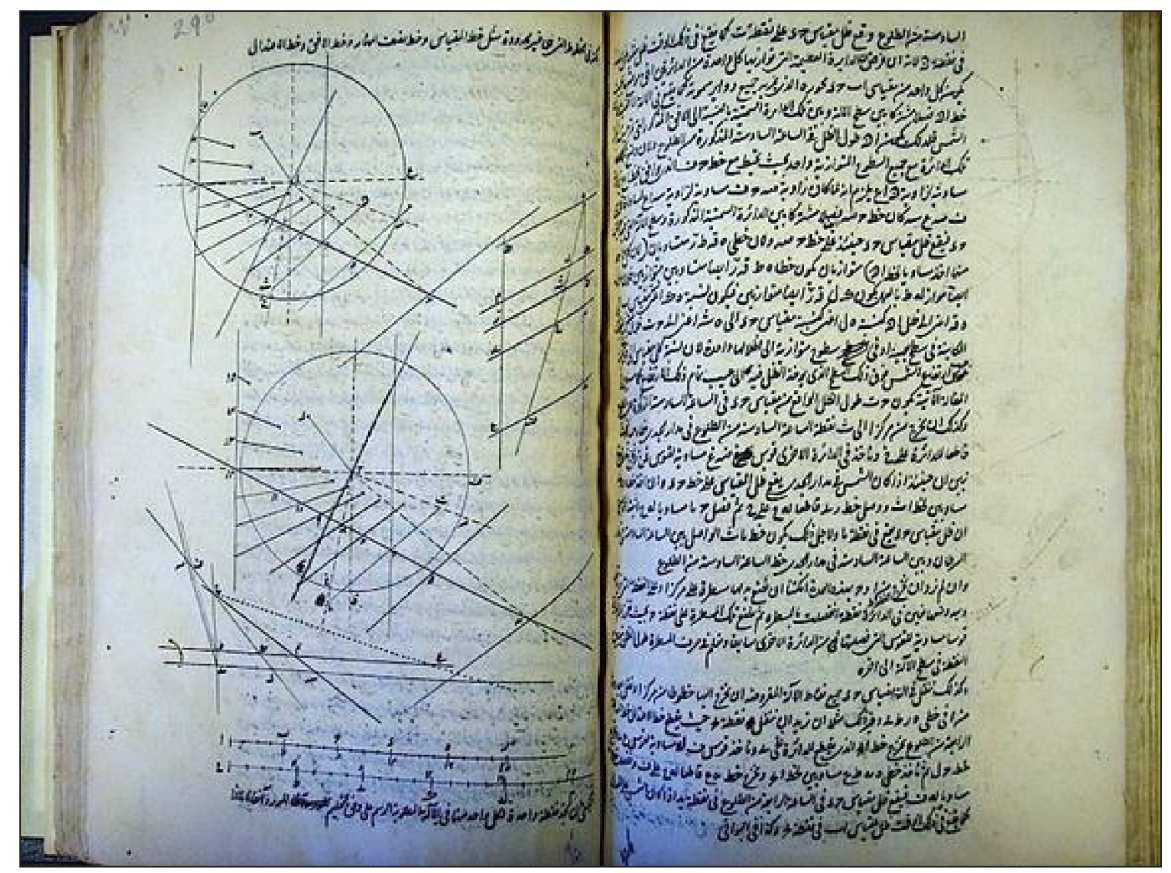

Fig. 2. Mu“tamid Khān’s Arabic translation of the identical passage (British Library IO Islamic 1308, ff. 289v-290) (Courtesy: British Library)

1792), where they caught glimpses of progressive British culture of Newtonianism, religious nonconformism, and entrepreneurial spirit. Awadhadministrator-scholar Tafaz̧zul Husain Khān (1727-1800) learnt English, Greek and Latin and translated Newton's the Principia from original Latin into Arabic. Excerpts from the translations are preserved in an erudite work called Tuhfat al'ālam (Gift to the World) of 'Abd al-Latîf Shushtarī (1758-1806) who lived in the neighbourhood of the scholar-translator at Kolkata. In 1793, Lucknow-born Abū Tālib ibn Muhammad Isfahān̄̄ (1752-1806) before his visit to Europe in $1800-3$, duly notes in the synopsis of his world history:

Europe was witnessing the birth of the great philosophers to the degree that even a great number of common people had developed philosophical disposition. The Europeans were seeking to relate themselves with the Greek philosophers, as if the Greeks themselves had become part of Europe's soil. (Lubb al-Siyār wa Jahān Nūmā (The Essence of World Biographies, Bodleian Library, Persian MS. Elliott 181 folio 393.)
Mirzā Shaikh I'tiṣām al-Dīn of Panchnoor in Nadia district of Bengal, recorded amazing experiments being carried out by the English scientists at the Oxford University's Astronomical Observatory and Faculty of Medicine during his stay in the beautiful University town in the autumn of 1766. He visited as an envoy of the Mughal Emperor Shah Alam II to George III and recorded his experiences in a travelogue entitled Shigarfnāma $i$ wilāyat (Wonder-Book of Europel England). Abū Tâlib also noted the use of the telescope in observational work which he observed at the Oxford University's Radcliffe Observatory as well as in the Greenwich Observatory (London). Muhammad Ḥusain ibn 'Abd al- 'Aḍ̄im Iṣfahān̄̄'s (d. 1790) knowledge of the western sciences was based on direct access, facilitated by his ability to translate English scientific works. His visit to Europe was motivated by his wish to acquaint himself with western scientific advances in the domain of astronomy and anatomy.

During my long social interaction and discourses, meetings and conversations I discovered about new 
thought and fresh discoveries about celestial mechanics, heavenly bodies, the nature of the terrestrial globe, and life on earth, discoveries of innumerable, hitherto unknown islands in the southern quarter of the globe, New World of America. Therefore, I attempted to elaborate upon some of these, such as the nature of the fixed stars and of the nature and shape of the planets etc. (Risālah-i- hiat-i Jadid Angrezi. University Collection Farsiya 'ulum No.18/1; Arabic version Arabia 'ulum, No. 33. Maulana Azad Library, Aligarh Muslim University, folios 1-2.)

'Abd al-Latīf Shushtarī identified three underlying factors for Europe's impressive scientific and technological achievements, namely the state patronage to the sciences and the specialization within particular scientific disciplines. Similar factors operated in the case of artisans and craftsmen, they too engaged in a particular occupation while the government encouraged their efforts by purchasing their products. Another reason for the flourishing of the sciences in Europe was the institutionalization of knowledge. I'tișām al-Dīn, Muhammad Husain, and Abū Tālib visited various educational institutions, societies, museums and observatories which to them reflected the intellectual advancement of Europe. The invention of printing was a potent means for the dissemination of ideas and knowledge. Abū Tālib occasionally attended meetings of the Royal Society which took place on weekends in the house of Sir Joseph Banks, the President of the Society. Abū Tālib writes:

\footnotetext{
During these meetings British scholars and scientists displayed their inventions and discoveries to their colleagues. They discussed their inventions with each other, sought each others' views and opinions in order to improve their inventions and exchanged ideas on abstruse matters (cf. Masir- $i$ Talibi fi bilad-i-Afranji, Travels of Abu Talib in the countries of Europe, Bodleian Library, Oxford, Ouseley Add. 108, folio, 107a).
}

'Abd al-Latīf added a new dimension to his discourse by pointing out that the research in astronomy was based on the application of mathematics and experimentation. The tables compiled by Islamic astronomers had gradually grown out of date and often contained errors and inaccuracies. Consequently, any results obtained from these were not reliable. In Europe the situation was quite different as no scientific discovery was considered definite but it was always subject to change (Tuhfat al-'álam Persian Manuscript Bodleian Library, Oxford, Elliot 382 folio 209).

\section{Reception of Modern Astronomy and Technological Advances}

Indo-Persian elites' discourses included a lucid exposition of the major principles and ideas of the modern astronomy from Copernicus's revolutionary conception of earth as one of the smaller planets of the solar system to Isaac Newton's (1643-1727) great synthesis of the physical world. They included Galileo's telescopic discoveries of Moon's of Jupiter and phases of Venus as well as Tycho Brahe and Johannes Kepler's laws of planetary motion. They attempted to write short biographical notes on Newton whom they considered the most illustrious and influential of scientists.

'Abd al-Latīf acknowledged his accomplishments in unequivocal terms.

The great philosopher (failasuf $i$ i'zam) Newton (Mister Neutan Hakim) was born in eleven hundred and twenty-eighth Hijra in England. He possessed a stupendous intellect, an excellent scholarly mind, scientific genius, and he was the doyen of the learned. Newton was a most extraordinary scholar, a wonder of his age, and a rarity in the world. It had been decades since a scholar of his calibre had appeared. His ideas on geometry and mathematics were cogent, coherent and perfect. His sayings (aqwal) and ideas constituted enduring truths for English scholars; the latter sought to identify themselves with his intellectual lineage and philosophy. Newton was a phoenix of his age and had no parallel in the contemporary world of scholarship. When some time ago his soul departed from this mortal world it left a permanent scar on the heart of the learned world. English scholars 
continued to pay high tribute to his achievements and assiduously kept cultivating his ideas on nature. It is said that in learning and scholarship he was the successor of Aristotle and Plato and even the Greeks became followers of his teachings (Tuhfat al-'àlam, folios, 158-9a).

Indo-Persian observers also witnessed British technical advances in the textile industry, shipbuilding, artillery. Some more Indians visited Europe in the nineteenth century. Karīm Khān 'Mushtāq' Jhajjari a resident of Jhajjar (Rohtak, Haryana) saw mid-Victorian Britain in 1839-41. He wrote extensively about railways, electric telegraph, and steamship in his travelogue entitled Siyāhatnāma, (Book of Travels), British Library, (London) OR. 2163, as well as a topographicalcum-universal history called Mir'āt-i-gītìnuma (The World reflecting mirror, British Library, Delhi Persian 724). Karīm Khān's account contains discourses on modern European sciences especially the new astronomy from the Copernicus's heliocentric world view to Herschel's findings in the sidereal astronomy as well as the industrial progress of the mid-Victorian Britain. He also availed the opportunity of holding scientific discussions with Sir John Frederick William Herschel (1792-1871), the British Royal Astronomer and geophysicist and the Frenchémigré engineer and inventor, Sir Mark Isambard Brunel (1769-1849). Tremendous improvement in the maritime technology was something he had also experienced personally during his extensive travel in Britain, Ireland, France and Greece. Therefore, it was the railways 'the great connector' which became main topic of Karīm's scientific and technical discourses (Khan, 2010, pp. 505-531; 2010, pp.151-55).

Karīm Khān's discourses of the western scientific and technical advances are less elaborate and less expressive as compared to the perceptions of the eighteenth century Indo-Persian writers. Karīm Khān lacked a penetrating bourgeoisie gaze in Faucauldian sense. The passiveness of his gaze reveals the fact of asymmetrical relationship of power between the colonizer and the colonized. For instance two of his major obsessions the railways and telegraph 'tools of empire,' were soon introduced in India, railways in 1846 and telegraph in 1852, as an agent of modernisation and social change but in the process Karīm had no say.

\section{Epilogue}

Compared to other parts of the Eastern world such as Japan and Turkey, India's response to the technical progress and the scientific advances in Europe did not come very late. The existence of such astonishing details of knowledge raises the question that indigenous agency and interlocutors could have played an important role in the diffusion of scientific ideas and knowledge. It has been rightly argued that the institutionalisation of western science and technology involved a complex interplay of structure and agency. Even in Europe these new ideas were at first understood only by the educated minority of the population. The difference lay in the fact that that minority was a dynamic element in its contemporary society and exercised profound influence on such aspects of that society as its religion, government, economic life and literature, all of which were also affected by the new science. But this was not so in India. Perhaps, men like Tafaẓul Husain Khān and Karīm Khān who were engaged in the task of production of knowledge, and refashioning of its scientific discourse, were face to face with the escalating process of marginalization. Regrettably the declining elite remained only passive recipients of knowledge. Tafazzul Husain's great scientific achievement the Arabic translation of Principia the brain-child of Newton remained confined in the pages of Tuhfat al- 'àlam of 'Abd al-Latīf Shushtarī.

Among the Urdu speaking elite the public intellectual, Sayyid Ahmad Khān, recognised the regenerative role of education, science and technology and formulated an active response to the scientific modernity. He founded the Scientific 


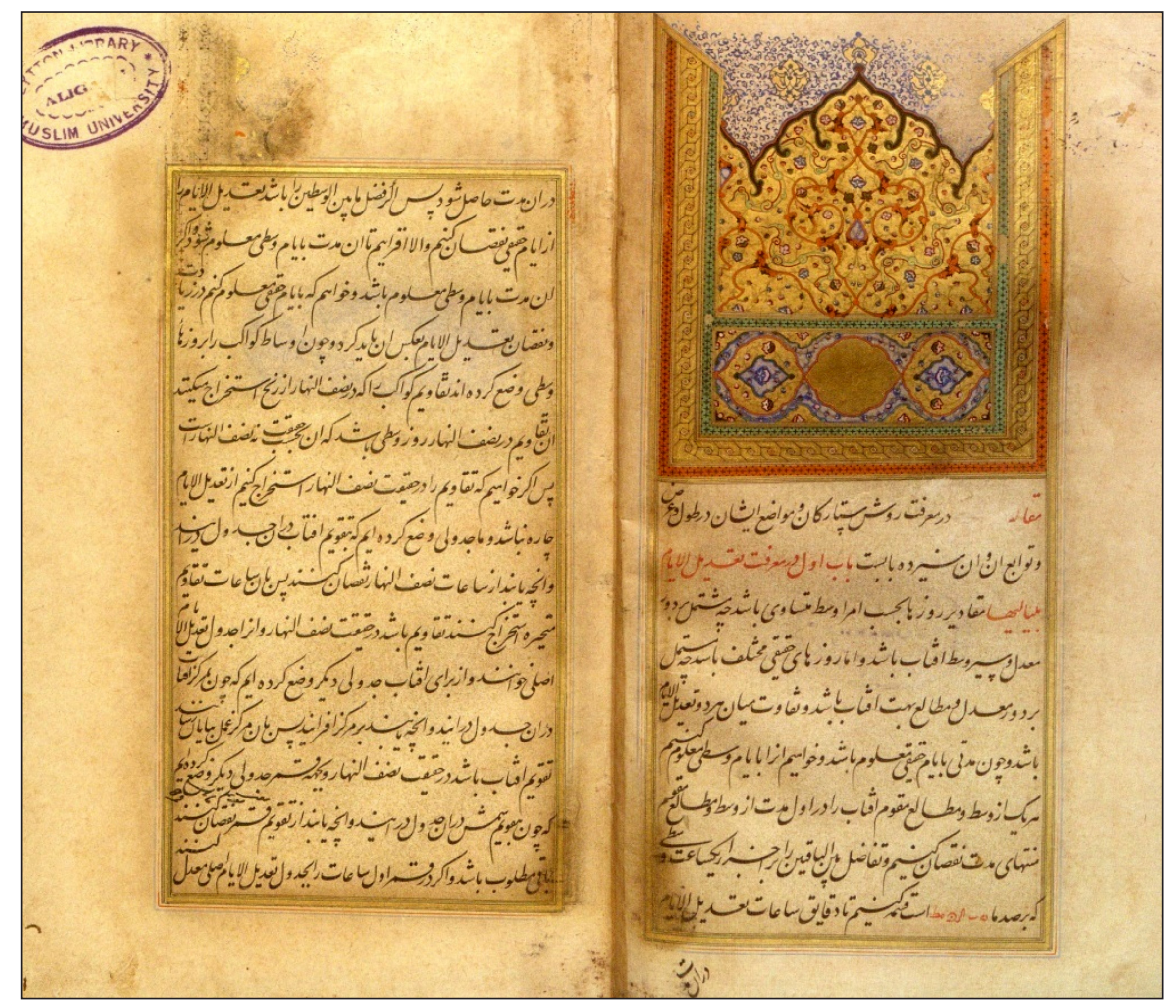

Fig. 3. Mirzā Ulugh Beg's Zīj-i-Ulughbegī Mss. 78/2 Persian Science (Courtesy: Maulana Azad Library)

Society in 1864 first in Ghazipur then at Aligarh. Its main task was to publish Urdu translations and original works on science, technology and agriculture. The Society also published a multi lingual journal called the Aligarh Institute Gazette, printed by Sayyid Ahmad's private press in moveable type. The journal carried publications in English, Persian and Urdu often in double columns with news and information about plant and animal life, human evolution, meteors and earthquakes, chemistry and physics, electricity telegraph, railways and photography. In addition the Society offered public lectures and maintained a laboratory and garden for diverse demonstrations and experiments such as popularization of new inventions (Abbas, 2014; Ali, 2015).

Many of the scientific manuscripts such as Zīj-i-Muhammad Shāhī (Ms. 30) and $Z \bar{\imath} j-i-$ Ulughbegī (Ms. 28) of Mirzā Ulugh Beg, preserved in the Maulāna Azad Library of the Aligarh Muslim University, belong to the private family collections of the founder. Some of these emanate from the collections of his maternal grandfather Khwājā Farīd al-Dīn Ahmad (17471828) a gentleman-scientist and maternal uncle Zain al-'Ābidīn (d. 1856) a manufacturer of scientific instruments. (Fig. 3).

\section{BiBLIOGRAPHY}

Abbas, Asghar (ed.). Sir Syed ki Scientific Society, Educational Book House, Aligarh, 2014.

Ali, Syed Asim (trans.) Print Culture: Sir Syed's Aligarh Institute Gazette 1866-1897, Primus Books, Delhi , 2015.

Alvi, M A and Rahman, A. Fathullah Shirazi, A Sixteen Century Indian Scientist, Indian National Science Academy, New Delhi, 1968, Reprint, 2011.

Habib, Irfan. The Technology and Economy of Mughal India, Indian Economic and Social History Review, 17.1 (1980):1-34.

Khan, Gulfishan, Indian Muslim Perceptions of the West during the Eighteenth Century, Oxford University Press, Karachi, 1998. 
Khan, Gulfishan. An Overview of the Scientific Thought and Technology in the Subcontinent during 18-19th Centuries, Insights, Vol. 01, no. 4 October- December (2009):39-76.

Khan, Gulfishan. XXIII International Congress of History of Science and Technology, (IUPHS/ DHST): A Report, Indian Journal of History of Science, 45.1(2010):151-55.

Khan, Gulfishan. Karim Khan and his Perceptions of Western Science during his visit to Britain 1840-41, Indian Journal of History of Science, 45.4 (2010):505531.

Khan, Gulfishan .The $25^{\text {th }}$ International Congress of History of Science and Technology (IUPHS/DHST): A Report, Indian Journal of History of Science, 52.4 (2017): 502507.
Qaisar, A Jan. The Indian response to European technology and culture, 1498-1707, Oxford University Press, Delhi, 1982.

Rahman, A. (ed.) Science Technology in Medieval India: A Bibliography of Source Material in Sanskrit, Arabic and Persian, National Science Academy, New Delhi, 1982.

Sen, S N. Influence of Indian Science on Other Culture Areas, Indian Journal of History of Science, 5. 2 (1970): 332-46.

Siddiqui, I H. Science and scientific instruments in the Sultanate of Delhi, Presidential address Section II, Indian History Congress, Mysore, Dec. 1993.

Siddiqui, I H. Delhi Sultanate Urbanization and Social Change, Viva Books, Delhi, 2009. 